\title{
ANALISIS WAKTU PEMUPUKAN TANAMAN SAWI HIJAU (Brassica rapa var. parachinensis) DENGAN TEKNIK PERUNUT RADIOAKTIF
}

\author{
THE ANALYSIS OF FERTILIZING TIME TO GREEN CABBAGE \\ (Brassica rapa var. parachinensis) PLANTS WITH RADIOACTIVE TRACER TECHNIQUE
}

\author{
Gusti Ngurah Sutapa, Ni Nyoman Ratini, Gde Antha Kasmawan \\ Jurusan Fisika FMIPA Universitas Udayana \\ Email: NGRmed@yahoo.com
}

\section{INTISARI}

Telah dilakukan penelitian analisis waktu pemupukan pada tanaman sawi hijau (Brassica rapa var. parachinensis) dengan teknik perunut radioaktif. Untuk menuju sistem pertanian berkelanjutan perlu adanya perbaikan pertanian (intensifikasi) selama beberapa tahun yang lalu masih signifikan, karena ketersediaan sumber daya alam dan teknologi pertanian cukup memadai dan berimbang dengan ketersediaan lahan dan peningkatan jumlah penduduk. Keadaan ini sulit untuk dipertahankan dimasa yang akan datang, kecuali ada pendekatan baru yang menawarkan ide dan teknik untuk meningkatkan produktifitas pertanian.

Efesiensi pemupukan tanaman dengan teknik perunut (tracer) radioisotop adalah salah satu potensi menuju sistem pertanian berkelanjutan. Teknik perunut dapat digunakan antara lain untuk mempelajari hubungan antara tanah dan tanaman, menentukan kondisi optimal dalam penggunaan pupuk (waktu pemupukan, pola perakaran aktif tanaman, jenis dan takaran pupuk), mempelajari proses dekomposisi dan mineralisasi bahan organik, serta mempelajari proses fotosintesis tanaman,baik dengan metoda langsung maupun tidak langsung. Waktu pemupukan yang lebih tepat dapat ditentukan dengan teknik perunut tersebut, sehingga optimalisasi pemupukan dapat dicapai, tanpa pemborosan yang tidak berguna.Dari penelitian dengan menggunakan radioisotop ${ }^{32} \mathrm{P}$, ternyata waktu pemupukan pada tanaman sawi hijau (Brassica rapa var. parachinensis) yang paling signifikan adalah pada pukul 9.00 pagi. Waktu siang hari mulai pukul 11.00 sampai pukul 15.00 adalah waktu pemupukan yang sangat buruk. Sedangkan waktu sore hari yaitu pukul 15.00 sampai 17.00 menunjukkan waktu pemupukan yang semakin baik namun tidak signifikan.

Kata kunci :waktu pemupukan, radioisotope ${ }^{32} \mathrm{P}$, teknik perunut.

\begin{abstract}
An extensive research on the analysis of fertilizing time to green cabbage (Brassica rapa var. parachinensis) plants had been done with a radioactive tracer technique. To gain a sustainable agriculture it is need to improve and increase the quality of agricultural production. Revision and improvement of the quality in agricultural production (intensification) for a couple of years ago is still significant, due to the availability of natural resources and agricultural technologies that was adequate and balanced with the availability of land and population increase. This situation is difficult to maintain for the coming years, unless there is a new approach that offers ideas and techniques to improve agricultural productivity.

Efficiency in plants fertilizing conducted with tracer techniques (tracer) radioisotope is one potent towards sustainable farming systems. Tracer techniques can be used to study the relationship between soil and plants, determine optimal conditions for the use of fertilizers (the time of fertilization, plant active rooting patterns, types and doses of fertilizers), to study the process of decomposition and mineralization of organic matter, as well as to study the process of plant photosynthesis, either by direct or indirect methods. More appropriate fertilization time can be investigated with this tracer technique, thus optimizing the fertilization can be achieved, without useless waste. Fromour research using radioisotopes ${ }^{32} \mathrm{P}$, most appropriaye time to fertilize green mustard plant (Brassica few var. Parachinensis) is at 9.00 am. Daylight started at time 11.00 until 15.00 is the worst time for fertilization. Whereas in the evening at $\mathbf{1 5 . 0 0}$ to 17.00 isalso a better time for fertilization but it is not significant.
\end{abstract}

Keywords: time of fertilization, radioisotope ${ }^{32} P$, tracer techniques. 


\section{PENDAHULUAN}

Definisi komprehensif bagi pertanian berkelanjutan meliputi komponen-komponen fisik, biologi dan sosioekonomi, yang direpresentasikan dengan sistem pertanian yang melaksanakan pengurangan input bahan-bahan kimia dibandingkan pada sistem pertanian tradisional, erosi tanah terkendali, dan pengendalian gulma, memiliki efisiensi kegiatan pertanian (on-farm) dan bahan-bahan input maksimum, pemeliharaan kesuburan tanah dengan menambahkan nutrisi tanaman, dan penggunaan dasar-dasar biologi pada pelaksanaan pertanian. Untuk menuju sestem pertanian berkelanjutan ini perlu adanya perbaikan dan peningkatan kualitas produksi pertanian (Nothoadiprawira, 2006).

Perbaikan dan peningkatan kualitas produksi pertanian (intensifikasi) untuk beberapa tahun yang lalu masih signifikan, karena ketersediaan sumber daya alam dan teknologi pertanian cukup memadai dan berimbang dengan ketersediaan lahan dan peningkatan jumlah penduduk. Keadaan ini sulit untuk dipertahankan dimasa akan datang, kecuali ada pendekatan baru yang menawarkan ide dan teknik untuk meningkatkan produktifitas pertanian (Ellafi, 2011). Efesiensi pemupukan tanaman dengan teknik perunut (tracer) radioisotop adalah salah satu potensi untuk memperoleh data atau informasi akan menjadi masukan untuk tindak lanjut perbaikan (problem solving) dari masalah yang dihadapi dari ancaman krisis pangan tersebut. Dengan segala kekurangannya teknik perunut diharapkan dapat membantu mengatasi permasalahan pembangunan pertanian yang tidak lagi dapat dipecahkan secara konvensional (Hakim, 2003).

Sampai saat ini radioisotop masih memberikan kesan menyeramkan dan bahkan menakutkan bagi sebagian orang. Namun, sesungguhnya radioisotop telah memberikan kontribusi yang berarti dalam kehidupan manusia.Radioisotop memberikan manfaat baik secara langsung maupun tidak langsung dalam menyelesaikan masalah yang dihadapi oleh umat manusia. Salah satu bentuk kontribusinya adalah teknik perunut (Wardana, 2007). Peran radioisotop sebagai perunut tidak terlepas dari sifat-sifat khas yang dimilikinya. Pertama, Radioisotop senantiasa memancarkan radiasi di manapun dia berada dan mudah dideteksi. Radioisotop ibarat lampu yang tidak pernah padam senantiasa memancarkan cahayanya. Radioisotop dalam jumlah sedikit sekali dapat dengan mudah diketahui keberadaannya. Dengan teknologi pendeteksian radiasi saat ini, radioisotop dalam kisaran pikogram (satu per satu trilyun gram) dapat dideteksi dengan mudah. Kedua, laju peluruhan tiap satuan waktu (radioaktivitas) hanya merupakan fungsi jumlah atom radioisotop yang ada, tidak dipengaruhi oleh kondisi lingkungan baik temperatur, tekanan, $\mathrm{pH}$ dan sebagainya. Penurunan radioaktivitas ditentukan oleh waktu paro, waktu yang diperlukan agar intensitas radiasi menjadi setengahnya.Waktu paro ini merupakan bilangan khas untuk tiap-tiap radioisotop. Ketiga, intensitas radiasi ini tidak bergantung pada bentuk kimia atau senyawa yang disusunnya.Hal ini dikarenakan pada reaksi kimia atau ikatan kimia yang berperan adalah elektron, utamanya elektron pada kulit atom terluar, sedangkan peluruhan radioisotop merupakan hasil dari perubahan pada inti atom. Keempat, radioisotop memiliki konfigurasi elektron yang sama dengan isotop lain sehingga sifat kimia yang dimiliki radioisotop sama dengan isotopisotop lain dari unsur yang sama. Radioisotop karbon-14, misalnya, memiliki karakteristik kimia yang sama dengan karbon-12. Kelima, radiasi yang dipancarkan, utamanya radiasi gamma, memiliki daya tembus yang besar.Lempengan logam setebal beberapa sentimeter pun dapat ditembus oleh radiasi gamma dengan energi tinggi. Sifat ini mempermudah dalam pendeteksian (Awaludin, 2009).

Berdasarkan pemanfaatan sifat-sifat khas radioisotop ini, dapat ditentukan waktu pemupukan tanaman dengan teknik perunut.Teknik perunut diharapkan dapat mengatasi permasalahan pembangunan pertanian untuk menuju siatem pertanian berkelanjutan.

\section{MATERI DAN METODE}

\section{Lokasi dan Tempat Penelitian}

Pembibitan dan pemeliharaan tanaman sawi hijau dilakukan di rumah pribadi didaerah Depok II Timur, Depok, Jawa Barat. Sedangkan pengaplikasian isotop ${ }^{32} \mathrm{P}$ pada tanaman sawi hijau di Green House laboratorium pemupukan dan nutrisi tanaman dilakukan di bidang Pertanian PAIR (Pusat Aplikasi Isotop dan Radiasi) BATAN, Pasar Jum'at Jakarta Selatan. Penelitian dilakukan pada bulan Mei 2015 sampai dengan Juli 2015.

\section{Presedur Penelitian}

Pembibitan dilakukan pada sebuah pot dengan tinggi $50 \mathrm{~cm}$ dan diameter $15 \mathrm{~cm}$ yang berisi media tanam berupa pupuk organik selama 14 hari. Pembibitan dilakukan dengan cara menaburkan benih sawi hijau diatas permukaan media tanam lalu ditutup kembali dengan tanah dengan ketinggian $\pm 2 \mathrm{~cm}$. Kemudian dilakukan pemeliharaan dengan cara disiram 2 kali sehari yaitu pagi dan sore hari. Setelah bibit berumur 14 hari, kemudian dipilih bibit yang terbaik dan dipindah penanamannya dalam polybag percobaan. Masing-masing polybag ditanam 1 bibit tanaman sawi hijau.Penanaman dilakukan selama 40 hari setelah tanam (HST) dengan jumlah daun \pm 6-7 daun. Kemudian dipilih 6 tanaman terbaik dengan kondisi tanaman yang hampir memiliki tinggi serta lebar daun yang sama. Kemudian 6 polybag berisi tanaman sawi hijau terbaik ditandai dengan sampel sesuai perlakuan yaitu perlakuan 1 (jam 07.00), perlakuan 2 (jam 09.00), perlakuan 3 (jam 11.00), perlakuan 4 (jam 13.00), perlakuan 5 (jam 15.00), dan perlakuan 6 (17.00).

Proses persiapan Isotop ${ }^{32} \mathrm{P}$ dilakukan di laboratorium PAIR BATAN. Isotop ${ }^{32} \mathrm{P}$ berupa cairan $\mathrm{KH}_{2} \mathrm{PO} 4$ dengan 
aktivitas jenis $2925 \mu \mathrm{Ci} / \mathrm{l}$ atau $108,225 \times 10^{6} \mathrm{~Bq} / \mathrm{l}$ dibagi kedalam 6 gelas beaker masing-masing $150 \mathrm{ml}$ per gelas beaker. Sehingga didalam $150 \mathrm{ml}$ mengandung aktivitas ${ }^{32} \mathrm{P}$ sebanyak $438 \mu \mathrm{Ci}$ atau $168,542 \times 10^{3} \mathrm{~Bq}$. Menurut IAEA (International Atomic energy Agency) aktivitas jenis ${ }^{2} \mathrm{P}$ yang umum digunakan adalah $0,5 \mathrm{mCi}$ atau $20 \mathrm{MBq}$ (Sisworo, 2006). Sehingga jumlah aktivitas ${ }^{32} \mathrm{P}$ yang diaplikasikan pada tanaman masih dalam ambang batas. Selanjutnya pengaplikasian Isotop ${ }^{32} \mathrm{P}$ pada tanaman sawi hijau dilakukan setelah tanaman berumur 40 hari di green house PAIR-BATAN. Dengan menyebarkan Isotop ${ }^{32} \mathrm{P}$ sebanyak $168,542 \times 10^{3} \mathrm{~Bq} / 150$ ml secara melingkar pada sekeliling area tanaman seperti ditunjukkan oleh Gambar 1.Waktu penyebaran dilakukan sesuai dengan jenis perlakuan, mulai dari perlakuan 1 sampai perlakuan 6 .

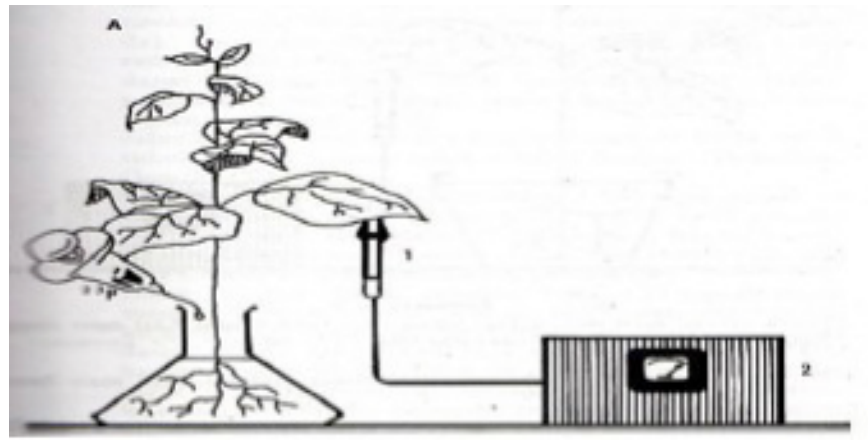

Gambar 1. Teknik perunut dengan unsur pospor (32P) yang diserap oleh tanaman melalui akar. ( Keterangan: 1. Detektor. 2. Radiation Alert Inspector.)

Proses pencacahan dilakukan 3 hari setelah 32Pdiaplikasikan pada akar tanaman. Kemudian dauntanaman dipanen dengan cara dipotong dari pelepah daun sesuai dengan perlakuan, daun dipanen atau dipotong sebanyak 6 halai daun yang dipilih secara acak. Sebelum dilakukan pencacahan daun ditimbang terlebih dahulu, selanjutnya dicacah menggunakan alat Radiation Alert Inspector dan dilakukan sebanyak 5 kali pengulangan pada setiap perlakuan tanaman.

\section{Analisis Data}

Data hasil pencacahan berupa count per second (cps). Data tersebut dikonversikan sehingga diperoleh nilai aktivitas dalam Satuan Internasional (SI) yaitu Becquerel (Bq). Untuk konversi nilai aktivitas32P sampel (cps) menjadi aktivitas 32P (Bq) dapat digunakan persamaan (1) sebagai berikut (Sisworo, 2006):

$$
d p s=\frac{c p s}{\eta}
$$

Dimana $1 \mathrm{~Bq}$ adalah satu peluruhan per detik (dps) Keterangan:

cps : cacahan per second

dps : desintegritas per second

$\eta \quad$ : efisiensi alat Radiation Alert Inspector
Untuk menentukan konsentrasi zat radioaktif yang terdapat pada daun sawi hijau digunakan persamaan (Wiryosimin, 1995) :

$$
X=A / m
$$

Dimana,

$\mathrm{X}$ : Kadar keradioaktifan daun sawi hijau (Bq/g)

A : Aktivitas 32P yang terserap oleh daun sawi hijau (Bq) $\mathrm{m}$ : Massa daun pada tanaman (g)

Selanjutnya data diolah dengan menggunakan program statistik ANOVA (Analysis of Varience) dengan menggunakan SPSS (Statistical Product and Service Solution).Pada analisis data ini digunakan program SPSS versi 17.0, yaitu SPSS versi 17.0 for Windows.

\section{HASIL}

Hasil cacahan aktivitas $32 \mathrm{P}$ dalam cps pada masingmasing pelakuan kemudian dilanjutkan mengkonversi nilai aktivitas 32P sampel (cps) menjadi aktivitas 32P (Bq) dengan persamaan (1), sehingga dapatditentukan konsentrasi zat radioaktif yang terdapat pada daun sawi hijau dengan persamaan (2). Kosentrasi radioaktif $32 \mathrm{P}$ ditunjukkan pada Tabel 1.

\begin{tabular}{|c|c|c|}
\hline \multirow{2}{*}{ No } & \multirow{2}{*}{$\begin{array}{c}\text { Perlakuan } \\
\text { (Jam) }\end{array}$} & Konsentrasi Isotop ${ }^{32} \mathrm{P}$ \\
\hline & & $(\mathrm{Bq} / \mathrm{g})$ \\
\hline 1 & $1(07.00)$ & $458.4 \pm 103.9$ \\
\hline 2 & $2(09.00)$ & $3961.8 \pm 157.7$ \\
\hline 3 & $3(11.00)$ & $1527.1 \pm 109.5$ \\
\hline 4 & $4(13.00)$ & $1166.2 \pm 129.3$ \\
\hline 5 & $5(15.00)$ & $1172.3 \pm 174.7$ \\
\hline 6 & $6(17.00)$ & $1623.7 \pm 184.1$ \\
\hline
\end{tabular}

Tabel 1. Konsentrasi radioaktif ${ }^{32} \mathrm{P}$

Konsentrasi radioaktif ${ }^{32} \mathrm{P}$ pada tanaman sawi hijau seperti Tabel 1. dapat direpresentasikan kedalam grafik, seperti ditunjukkan pada Gambar 2. berikut,

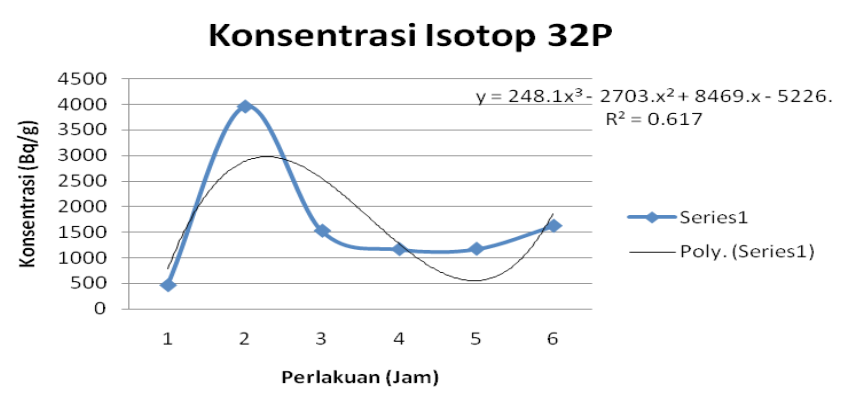

Gambar 2. Konsentrasi radioaktif ${ }^{32} \mathrm{P}$ tertinggi (jam 09,00) pada tanaman sawi hijau.

\section{PEMBAHASAN}

Aplikasi teknik perunut pada tanaman memiliki keunggulan seperti lebih mudah mendeteksi keberadaan radioisotop atau unsur hara yang terdapat pada tanaman sawi hijau dengan mengunakan detektor radiasi dari 
luar tanaman, tanpa melakukan pembedahan terhadap tanaman untuk mengetahui unsur hara tersebut (Purwanto, 2007). Radioisotop ${ }^{32} \mathrm{P}$ yang digunakan pada penelitian ini adalah unsur radioisotop yang paling mudah diserap tanaman sawi hijau dibandingkan dengan unsur $\mathrm{N}$ dan $\mathrm{K}$, merupakan unsur-unsur yang biasa digunakan sebagai perunut (Alam, 2001). Sawi hijau memiliki kandungan kalori, protein, lemak, karbohidrat, serat, Ca, P, Fe, Vitamin A, Vitamin B, dan Vitamin C, lebih tinggi dibandingkan dengan tanaman sayur lainya. Sawi hijau memiliki luas permukaan daun yang lebar sehingga lebih mudah dideteksi keberadan unsur hara yang terdapat pada tanaman.

Dari Gambar 2 diatas diketahui bahwa konsentrasi zat radioaktif yang terkonsentrasi pada tanaman sawi hijau untuk perlakuan 2 mengalami peningkatan sangat tinggi dibandingkan dengan perlakuan lainnya. Dimana perlakuan 1, 3, dan 4 mengalami penurunan, kemudian mengalami peningkatan kembali mulai perlakuan 5 dan 6. Dari persamaan regresi polynomial, tanda positif dari koefisien $\mathrm{x}$ menyatakan peningkatan isotop ${ }^{32} \mathrm{P}$ yang diserap oleh daun tanaman sawi hijau.Sedangkan tanda negatif dari koefisien $\mathrm{x}$ menunjukkan bahwa isotop ${ }^{32} \mathrm{P}$ yang diserap oleh daun tanaman sawi hijau mengalami penurunan. Sehingga dapat dinyatakan bahwa waktu atau jam makan tanaman sawi hijau (pemupukan) yang paling baik adalah pada perlakauan 2 atau pada waktu jam 09.0o pagi dan pada pelakuan 6 atau pada waktu jam 17.00 sore. Hasil penelitian tersebut mendukung pernyataan Hardjowigeno (1995) bahwa saat pertumbuhan reproduktif tanaman membutuhkan unsur N, P dan K. Unsur P diserap oleh tanaman dari pupuk diwaktu pagi dan sore hari pada saat kelembaban meningkat, sedangkan pada siang hari pupuk dengan konsentrasi tinggi cenderung menjadi hipertonis karena air menguap, sehingga pupuk tidak dapat diserap maksimal oleh tanaman. Evapotranspirasi juga menjadi salah satu penyebab waktu pemupukan pada siang hari menjadi tidak efektif dikarenakan terjadinya penguapan atau perpindahan sejumlah air dari permukaan tanah dan tanaman langsung ke atmosfer (Nishio, 1998).

Aplikasi pemupukan hendaknya memperhitungkan sinar matahari. Pada saat siang terik, pupuk akar yang mudah menguap, seperti urea, tidak akan sempat diserap oleh tanaman. Begitu juga pupuk yang diaplikasikan lewat daun. Pelarut atau air akan cepat menguap bila terkena sinar matahari yang terik. Selain itu, mulut daun pada saat matahari terik akan menutup sehingga keberhasilan pemupukan pada saat matahari terik semakin kecil. Oleh karena itu, pemupukan sebaiknya dilakukan sebelum atau sesudah matahari bersinar terik. Pemupukan yang baik dilakukan sebelum pukul 10.00 atau sesudah pukul 15.00 sore. Diluar waktu itu, pemupukan dapat dilakukan bila tanaman berada dibawah naungan yang tidak memungkinkan adanya sinar matahari terik atau di daerah dataran tinggi dimana sinar mataharinya tidak terik (Heru, 2007).
Untuk melihat perbedaan waktu pemupukan yang signifikan atau tidak juga dapat ditunjukan pada hasil Homogenous Subset seperti Tabel 2.

Tabel 2. Homoginitas Subset dengan uji Tukey HSD

\begin{tabular}{cccc}
\hline Perlakuan & Ulangan & Subsets & $\alpha=0.05$ \\
\hline & & 1 & 2 \\
$1(07.00)$ & 6 & 1234,9333 & \\
$4(13.00)$ & 6 & 2435,0667 & \\
$5(15.00)$ & 6 & 2976,0000 & \\
$3(11.00)$ & 6 & 3495,8667 & \\
$6(17.00)$ & 6 & 3947,6000 & \\
$2(09.00)$ & 6 & & 8800,5333 \\
\hline
\end{tabular}

Dari Tabel 2 terlihat bahwa perlakuan 2 secara signifikan mengalami perbedaan dengan perlakuan 1, 3, 4, 5 dan 6. Pada homogenitas subset dapat dilihat perlakuan 2 berada pada kolom 2 sedangkan perlakuan 1, 3 4, 5 dan 6 terdapat pada kolom yang sama yaitu kolom 1. Sehingga perlakuan 2 menunjukan konsentrasi zat radioaktif tertinggi yang terkandung pada tanaman sawi hijau. Ketepatan waktu pemupukan seperti yang terjadi pada perlakuan 2 atau pada jam 09.0o pagi dapat menghindarkan pemborosan terhadap penggunaan pupuk serta dapat mengatasi permasalahan pembangunan pertanian untuk menuju siatem pertanian berkelanjutan.

\section{SIMPULAN}

Teknik perunut dapat digunakan untuk menentukan kondisi optimal dalam penggunaan pupuk (waktu pemupukan). Waktu pemupukan yang lebih tepat dapat ditentukan dengan teknik perunut, sehingga optimalisasi pemupukan dapat dicapai, tanpa pemborosan yang tidak berguna. Radioisotop ${ }^{32} \mathrm{P}$ yang paling banyak terkandung pada tanaman sawi hijau pada perlakuan 2 (jam 09.0o) dengan jumlah konsentrasi sebanyak 2984,102 Bq/gr yang artinya waktu pemupukan yang paling signifikan adalah pada jam 09.00. Waktu siang hari mulai pukul 11.0o sampai pukul 15.0o adalah waktu pemupukan yang sangat buruk. Sedangkan waktu sore hari yaitu pukul 15.0o sampai 17.0o menunjukkan waktu pemupukan yang semakin baik namun tidak signifikan.

\section{KEPUSTAKAAN}

Alam M. S., 2001. Application Radioisotopes and Radiation in the Field of Agriculture : Review. OnLine J. Biol. Sci. 1(3)

Awaludin R., 2009. Mencari Jejak Menggunakan Radioisotop, Reaktor nuklir G.A. Siwabessy Serpong.

Ellafi, A.M. G., 2011. Biofertilizers in Action: Contributions of BNF in Sustainable Agricultural Ecosystems. E-Int. Sci. Res. J.3.

Hakim R., 2003, Komponen Perancangan Arsitektur Lansekap Prinsip-prinsip dan Aplikasi Desai Teknik Nuklir. Bumi Aksara. Jakarta.

Hardjowigeno, S. 1995. Ilmu Tanah. Akademika Pressindo. Jakarta.

Heru, P. 2007. Memupuk Tanaman Sayur. Penebar Swadaya. Jakarta. 
Nishio, T. 1991. ${ }^{15} \mathrm{~N}-\mathrm{NH}{ }^{+}$Isotop Dilution Method for Analyzing Nitrogen Transformation in Upland Soils. JARQ 25 (2).

Nothoadiprawira T., 2006. Pengelolaan Kesuburan Tanah dan Peningkatan Efisiensi Pemupukan. Ilmu Tanah, Fakultas Pertanian, UGM.

Purwanto H., 2007, Teknologi Perunut ${ }^{15} \mathrm{~N}$ untuk Mengkaji Transformasi Nitrogen pada Tanah dan Tanaman dengan menggunakan Spektrofotometer Emisi. J.Ilmu Tanah dan Lingkungan $7(1)$.

Sisworo, E.L., K. Idris, A. Citraresmini, dan I. Sugoro. 2006. Teknik Nuklir untuk Penelitian Hubungan Tanah-Tanaman, Perhitungan dan Interpretasi Data.BATAN. Jakarta.

Wardana W.A., 2007. Teknik Nuklir ; Proteksi Radiasi dan Aplikasinya. Penerbit ANDI Yogyakarta.

Wiryosimin, S., 1995. Mengenal Asas Proteksi Radiasi. Bandung: ITB 